\section{Standards for Surgical Dressings}

ThE Pharmaceutical Society of Great Britain has issued a report on "Dressings" by a sub-committee of the Codex Revision Committee (Pharmaceutical Press, 23 Bloomsbury Square, London, W.C.1. 1s. 6d.). It contains a summary of standards for surgical dressings, provisionally accepted for inclusion in the British Pharmaceutical Codex, 1934, which should provide information useful for manufacturers and others. The standards suggested include those for the basic materials, such as jute, silk and wool, and for dressings such as phenol and mercuric chloride gauzes, and others, as well as methods for the determination of moisture, water extract, foreign matter, cotton and wool in the dressings.

\section{Benefits to Animals from Animal Experiments}

The autumn issue of the Fight Against Disease, the quarterly journal of the Research Defence Society, contains the concluding portion of Sir Leonard Rogers' Stephen Paget Memorial Lecture. After a survey of some of the principal animal and virus diseases, Sir Leonard concludes that "the examples given from the limited field of tropical medical and veterinary science alone, suffice to prove that the reduction in the suffering that results year by year to animals, as well as to man, from the discoveries made in about three decades through a limited number of animal experiments, is incalculably greater than the pain inflicted on the animals under our humane laws".

\section{Leverhulme Research Fellowships}

Applications are now invited for Leverhulme research fellowships for 1934. These fellowships are intended in the first instance for the assistance of experienced workers rather than to add to the provision already existing for workers in the early stages of their careers. It has been decided that no definite limit shall be placed to the amount of individual grants, but that they will be adjusted according to the circumstances of each particular case. Fellows will usually be required to work at, or in connexion with, a recognised centre of research, either at home or abroad. No subject of inquiry is excluded from the scope of the scheme. Awards will not be made, as a rule, for a shorter period than three months or for a longer period than two years. The closing date for receipt of applications is March 1. The awards will be announced in July and will date from September 1. All applicants must be British-born and they must also be normally resident in the United Kingdom. Further information can be obtained from Dr. L. Haden Guest, Secretary, Leverhulme Research Fellowships, Union House, St. Martins-le-Grand, London, E.C.1.

\section{Announcements}

DR. L. W. G. MaLCoLm, conservator of the Wellcome Historical Medical Museum, has been appointed an officer of the Venerable Order of the Hospital of St. John of Jerusalem.
THE following appointments in the Colonial Agricultural Service have recently been made : Dr. F. J. Martin, assistant director of agriculture, Sierra Leone, to be director of agriculture, Sierra Leone; R. S. Ball and J. T. Moon to be agricultural officers, Kenya.

Aт the ordinary meeting of the Institution of Electrical Engineers to be held on January 18, at 6 p.m., Viscount Falmouth will present to the Institution a copy of Sir William Orpen's painting of Sir Charles Parsons.

A JorNT meeting of the Royal Astronomical Society and the Geological Society will be held in the rooms of the Royal Astronomical Society, Burlington House, W.1, on January 26, at 4.30 p.m., when a discussion will be held on the "Origin of the Earth's Major Surface Features". The meeting will be presided over by Sir Frank Dyson.

THe annual meeting of the International Society of Medical Hydrology is to be held on January 28February 2 at Zurich, Davos and St. Moritz. The president elect is Prof. O. Veraguth, professor of physical therapy in the University of Zurich. The principal subjects for discussion are the thermal bath reaction and the physiological and therapeutic effects of high mountain climates. Decisions will be taken concerning the nomenclature and classification of muds, peats, etc., used in physical medicine. The meeting is open to scientific workers generally as well as medical men. Further information can be obtained from the General Secretary, I.S.M.H., 109 Kingsway, W.C.2.

WE have received the 1934 pocket diary of Messrs. John G. Stein and Co., Ltd., silica and firebrick manufacturers, of Bonnybridge, Scotland. The diary contains many features of interest, for example, chemical analysis of various types of firebrick; special refractories, their analyses, expansion curves, thermal properties, etc.; equilibrium diagram of the system $\mathrm{Al}_{2} \mathrm{O}_{2}-\mathrm{SiO}_{3}$ (Bowen and Greig); first aid treatment; standards of measurement, and their equivalents ; sectional road maps of Great Britain; and much other useful standard information.

Applications are invited for the following appointments, on or before the dates mentioned :-An examiner in the aeronautical Inspection Department of the Air Ministry-The Secretary (S.2), Air Ministry (Jan. 15). A maintenance and test engineer in the Public Works Department, Electricity Branch, Government of the Punjab-The High Commissioner for India, General Department, India House, Aldwych, London, W.C.2 (Feb. 1). A demonstrator in dairy husbandry and an advisory entomologist in the Department of Agriculture, University of Leeds-The Registrar (Feb. 2). A head of the Departments of Municipal Engineering in the Manchester Municipal College of Technology-The Regis. trar (Feb. 5). An agricultural chemist and an entomologist at the Imperial Institute of Agricultural Research, Pusa-The High Commissioner for India, General Department, India House, Aldwych, London, W.C.2 (Feb. 12). 